\title{
Assessing the impact of tourism: intellectual and economic struggles and landscape changes on Kihnu island
}

\author{
P.-K. Parts \& K. Sepp \\ Institute of Agricultural and Environmental Sciences, \\ Estonian University of Life Sciences, Estonia
}

\begin{abstract}
Issues of the assessment of the impact of tourism on the cultural environment will be discussed using the example of Kihnu island (Estonia), which has been included in the list of Masterpieces of the Oral and Intangible Heritage of Humanity by UNESCO as the Kihnu Cultural Space. Kihnu is a small island $\left(16.9 \mathrm{~km}^{2}\right)$ near the eastern coast of the Baltic Sea, and has a population of about 530 residents. After the collapse of the Soviet Union, traditional economic activities like fishery and agriculture have undergone a severe decline; instead, new economic activities such as tourism, the sale of traditional delicacies, handicrafts etc., have become an important source of income on Kihnu. These changes have had a great influence on the cultural and natural landscapes of the island, as well as on social and political relationships, and have brought together manifold conflicts between the interests of tourism and the traditional economy, the different agendas of local interest groups and the cultural and economic elite, national policies etc. The interpretive analysis of official planning texts and interviews with different local actors indicated the remarkable sensitivity of the issues concerning tourism, resulting often in a euphemistic way of defining problems and development priorities in the field. As environmental impacts can only be assessed in relation to certain socially defined objectives, the described situation makes it very complicated to assess the impact of tourism or to offer up-to-date recommendations concerning tourism for the protection of both the natural and cultural environment. Nevertheless, in order to advance a further discussion on the assessment of the impact of tourism, initial explorative indicators will be set out, relying on the example of Kihnu.
\end{abstract}

Keywords: tourism impact assessment, cultural environment, participatory methods, indicators. 


\section{Introduction}

This article is based on a study commissioned by the Ministry of the Environment of the Republic of Estonia [1], the objective of which was to assess the tourism carrying capacity of the cultural environment of the island of Kihnu from the point of view of cultural, landscape and natural values (Parts et al). Since an environment's carrying capacity can only be assessed in relation to particular objectives that have been established in a society, we were faced with the need to ascertain those objectives. Unfortunately, however, development plans, legislation and international laws concerning the relations between tourism and the natural and cultural environment are worded in an extremely declarative form and do not contain sufficiently clear and explicit development goals. There is also a lack of corresponding research and political precedents in Estonia. In this situation, our research could only be a mapping of possible dangers and areas of conflicting interests. We set ourselves the primary objective of defining explorative indicators in order to evaluate the tourism carrying capacity of the cultural environment of Kihnu.

The cultural environment is a political concept that is difficult to define, since its meaning depends on the corresponding context of its use and objectives in each case, which often are not clear-cut. In this case we define the cultural environment as all manner of human activities and the preconditions for those activities, which are connected in a broad sense to the welfare and cultural heritage of the cultural landscapes of Kihnu, to the extent that these concepts are comprehensible through corresponding plans [2-8], research [9-11], political documents [12], legislation [13,14] and the opinions of stakeholders (newspaper articles, interviews and observations made during field work).

Since tourism is by nature an international phenomenon and there was an absence of Estonian precedents, we had to seek data from international experiences and agreements. In developing our recommendations, we took into consideration the experiences and recommendations of the relevant international organisations (e.g. WTO [World Tourist Organisation], UNEP [United Nations Environment Program] [15], VASAB [Vision and Strategies around the Baltic Sea 2010][16], UNESCO [17]) for the organisation of tourism, spatial planning and the protection of the cultural environment. Since a Sustainable Development Act [18] has been passed in Estonia, we considered it appropriate to base our research on the EUROPARC Federation's position, which defines sustainable tourism as "all forms of tourism development, management and activity, which maintain the environmental, social and economic integrity and well-being of natural, built and cultural resources in perpetuity" Shipp and Kreisel [19].

\section{Historical background: culture and economy}

Kihnu is a small Estonian island $\left(16.9 \mathrm{~km}^{2}\right)$ with about 530 inhabitants off the eastern coast of the Baltic Sea, in the Gulf of Riga. The island has been entered in the UNESCO List of the Masterpieces of the Oral and Intangible Heritage of Humanity as the Kihnu Cultural Space [12]. The justification for entering the 
island in the list was the island's extraordinary ethnic uniqueness resulting from the island community's geographic isolation: this was expressed in language, customs and material culture, for instance in the fact that the locals to this day wear folk costume in everyday situations [12]. Historically, the central sources of subsistence have been fishing, seal hunting and seafaring, while farming, herding and homemaking have mainly been women's work [20,21].

This way of life continued largely unchanged until the collapse of the Soviet Union, although in a semi-industrial form Levald [22, 23], and the corresponding moral attitudes are deeply rooted in the value system of the Kihnu community. Of traditional sources of subsistence, fishing has largely retained its position in the island's economy, although the poor condition of the Baltic Sea's fish stocks and EU directives are continually reducing its position Vetemaa et al [24]. It is very common for people to work both at sea and on mainland, and since the 1990s also abroad, particularly in Finland. Working abroad is in itself a phenomenon with long traditions, although the fact that it increasingly involves women is a new aspect.

The island's scarce natural resources and weak economy by contemporary standards were already noted in the 1980s [22, 23], although the Soviet period has gone down in the popular memory as an era of prosperity and stability due to the state subsidies and the special status of the fisheries. The collapse of the Soviet Union and the accompanying gradual diminishing of the fishing industry, as well as Estonia's transition to a market economy have led to a reduction in state subsidies, although several indicators show that Kihnu remains one of the most subsidised regions of Estonia Servinski [25]. As an example of the inefficiency of the island's infrastructure, the 1994 general plan mentions that "the consumption of electricity surpasses that of many European [i.e. Western European] countries" Kerge et al [3], and the statistics also note the island's excessive motorisation Kerge et al [4]; subsequent state policies have favoured the increasing of ferries' capacity to transport automobiles to and from the island $[6,7]$; Alop [26], which further increases pressure on natural environment and the island's roads, which are already in a poor condition.

After Estonia regained its independence in 1991, the number of tourists visiting the island increased dramatically. In 1995 the general plan for Kihnu Parish does, indeed, specify that "a maximum of 100-125 tourists may visit the island at one time, (...) 5000 tourists on 2.5 days [per year], without mentioning how the decision would be implemented [4]. This figure has long ago been surpassed. According to Annely Akkermann, manager of tourism and the ferry line, which is the island's leading tourism-related company, and now parish mayor, the number of tourists visiting Kihnu exceeded 10,000 since at least 1998 [27], and remained stable since 1999 [28]). Reliable sources, however, are in short supply; for instance, Johannes Leas, the owner of the competing ferry company and parish mayor at the time we interviewed him, stated that the number of visitors was approximately 30,000 [29].

According to a 2002 study, $25 \%$ of Kihnu residents estimated that their work depended to a great extent on tourism, while $28 \%$ answered 'occasionally' Hurt et al [11]. This points to the island economy's significant dependence on 
tourism. The fact that this dependence is not only seen as a positive thing is highlighted for instance by the fact that the 1995 general plan set an upper limit for the number of visitors [4]. The following entry in the Kihnu parish electronic guestbook from 27 May 2004 is apparently also indicative: "Attention all tourists. We would be glad if you would NOT COME HERE!” [30]

\section{Methodology and data gathering}

The methodological models that we have used for this study are the critical approaches that have developed in international development aid practice, which are best known under the names 'participatory methods' or RRA and PRA (Rapid/Relaxed and Participatory Rural Appraisal) methods. These methods are characterised by an emphasis on practice, agency, interdisciplinarity, a holistic approach and the serious consideration of popular/indigenous knowledge Mikkelsen [31]. As seen by these approaches, the researcher is an agent of social change, and the research is a mutual learning process between researcher and the objects of the research. From the researcher's point of view, this approach means an economical learning opportunity, which is particularly important in this case, where there was an almost complete absence of earlier research and reliable statistics. In the case of RRA and PRA, we base our deductions on the principle of the optimal ignorance, according to which the researcher must know what and how much is worth knowing [31]. Documented data, direct observations, possible future and scenario workshops, etc. are given equal weight. In the analysis, different types of data and methods in different forms and from different disciplines will be cross-checked (triangulation).

In this study we have used direct observation and analysis of existing research alongside the so-called informal conversational interview type of semistructured interviews in order to assess the social carrying capacity of the Kihnu community [31]. The advantage of this approach is the creation of a casual atmosphere in the interview situation, in order to achieve as trusting an atmosphere as possible in a short time, and obtain access to information and views that informants otherwise would not disclose to the interviewer. In order to create a trusting atmosphere, recordings were not made during the interviews (although some informants suspected us of this despite our assurances to the contrary), and the results of the interviews were entered in the research diary at the end of the observation day. Excerpts from the fieldwork diary were used to illustrate the analysis. All names and other references that could permit identification have been left out, and personal reference is only made to those informants who explicitly did not wish to conceal their identity.

In total, about thirty residents of Kihnu were thoroughly interviewed (for a quarter of an hour or more), both individually and in groups, depending on the situation. Although the delimiting of a community is a broad topic in itself (see for instance Cohen [32]; Richards \& Hall [33]) and also the content of the concept "kihnlane" [resident of Kihnu] depends to a certain extent on the person using the word, in this case we considered the broad definition of community through indigenousness to be sufficient. The fieldwork consisted of visiting 
Kihnu as a passive observer in the role of a tourist (2.08-7.08.2004) and an interviewing session (20.11-27.11.2004). In addition, we performed longer interviews (an hour or longer) with certain key persons whose main connection with Kihnu was of a business nature.

In interpreting the interviews and written documents, we as researchers considered it important to avoid the naïve presumption that the individual or collective accounts, whether oral or written, of the persons we studied would give a pure and reliable view of their mental state, attitudes and values. Our research is based on the discourse analytical approach, which stems from the belief that language does not represent things "as they are", but considers it an active medium used to construct reality Laclau and Mouffe [34] or at least a "detached commentary on reality" Burningham [35]. Discourses can be defined as "the broad systems of thought, which inform how we conceive of the world and gain practical expression in regulative institutions; they are vehicles of social power and serve as strategies of moral manipulation" Livingstone [36], cited from Jones [37].

In discourse analytical study, instead of searching for "absolute and objective truth", one concentrates on how reality is constructed in social practices, including scientific research Foucault [38]. Research itself is understood more as making in a rhetorical process of negotiations than finding some already existing social regularity Shotter [39]. Discourse analysis is an interpretative analysis. Interpretative analysis of this kind is an active and creative way to read the research material, while in constructing the discourses new ways for categorizing and conceptualising social reality are constructed at the same time Jokinen and Juhila [40].

\section{Tourism carrying capacity: an elusive concept}

In their joint publication, the WTO (World Tourist Organisation) and UNEP (United Nations Environment Program) have defined tourism carrying capacity as follows: "Carrying capacity' is the level of visitor use an area can accommodate with high levels of satisfaction for visitors and few impacts on resources. Carrying capacity estimates are determined by many factors; in the end, they depend on administrative decisions about approximate sustainable levels of use. The major factors in estimating carrying capacity are (a) environmental, (b) social, and (c) managerial." McNeely et al [41]

Boullón [42], cited from McNeely et al [41] offers a quantitative formula for the assessment of tourism carrying capacity (see Table 1).

The "individual standard" is, however, very difficult to define and measure (as acknowledged by McNeely et al [41], and the area used by tourists cannot generally be determined unequivocally, at least not in the case of Kihnu. A considerable proportion of tourists move around independently on the island, and tourism use is difficult to distinguish from the activities of the local inhabitants, and moreover, in the case of community tourism, the community and thus also the land it uses is part of the tourism product (see Richards and Hall [43]). 
Table 1: $\quad$ A formula to estimate tourism carrying capacity by Boullón [42].

Carrying capacity $=$ Area used by tourists/Average individual standard

The total number of allowed daily visits is obtained as follows:

Total of daily visits $=$ Carrying capacity $*$ Rotation coefficient

Where the rotation coefficient is determined thus:

Rotation coefficient $=\mathrm{N}$ of daily hours open for tourists/Average duration of visits

Although the above-mentioned formula appears objective, it therefore contains variables that by nature are purely conventional. Until a political agreement has been reached concerning the content of these variables, it is neither legitimate nor practicable. Due to the above-mentioned difficulties, the authors of this research initially limited themselves to qualitative assessments. We prefer to assess/describe Kihnu's tourism carrying capacity through tourists' behavioural patterns and against the background of Kihnu residents' wishes and preferences and requirements established by law or international agreements. We define behavioural patterns as tourists' manners of movement and routes, time use (time and duration of visit during the year, the timing of activities by days and weeks and by days of the week or holidays), consumption preferences, their conduct, etc.

\section{Analysis of the thinking about the development of tourism on Kihnu Island: critical comments}

Since the objective of the research on which this article is based was to offer recommendations for the organisation of tourism, one cannot avoid taking a position vis-à-vis the established understandings and vocabulary about tourism that already function in this discourse. Concepts such as "mass tourism" [3], "elite tourism" [3-5], “ecotourism" [44], alcohol tourism [12], "cultural tourism", "quality tourism" [5] are presently in use.

The concept "elite tourism" is explained in Kihnu's general plan as follows: "In order to restrain mass tourism, we must orient ourselves towards elite tourism, i.e. tourists who arrive via yacht or plane." [3] The above-mentioned general plan's penchant for elite tourism can apparently be explained by the objective of thoroughly reconstructing the yacht harbour. The plan recommends a harbour with a capacity that exceeds the real visitation (223 yachts per season) of that which existed at the moment the plan was prepared (1994) almost tenfold (2000 yachts!), and predicts that the payback period for the reconstruction will be eight years. In actual fact, the number of visitors on yachts has remained stable [45]. A later consumption profile study performed in 2002 noted that almost all yacht tourists sleep on their yachts [11], thus only leaving an insignificant amount of money on the island, while requiring notable investments 
in infrastructure. In the situation in which even now Kihnu Parish receives the most state budget subsidies per capita of almost all local governments in Estonia [25], such elite tourism that is oriented mainly towards the foreign market would reduce the Estonian government's economic motivation to make expenditures on infrastructure, especially in the area of ferry traffic, which is of vital importance to the island's residents as well as "mass tourists".

The parish's development plan for the years 2003-2008 [5] formulates the objective of quality and not quantity of tourism. In the application for inclusion on the UNESCO List of the Masterpieces of the Oral and Intangible Heritage of Humanity, the applicants set the objective of replacing "alcohol tourism" and "consumer tourism" with "well-organised cultural tourism" [12]. The meaningfulness of these concepts is nevertheless discredited when compared with the empirical data. According to the visitor study performed in $2002,32 \%$ of visitors to Kihnu are campers, and over one half of visitors do not spend money on purchases $(65 \%)$ or entertainment $(62 \%)$, but the main expenditures are the ferry ticket, food and drink (in precisely that order!) [11]. The local handicraft artists also confirmed in the interviews that Kihnu handicrafts are mostly too expensive for Estonians. Against that background, it appears to be suitable to speak of "consumer tourism" precisely in the case of the so-called cultural tourists, since the former need accommodation, purchase handicraft products, order folklore performances, etc.

This conception of cultural tourism would, however, require a revolutionary reorientation of the Kihnu tourism business towards elitist, mainly foreign consumers, as well as a special service infrastructure and specially trained assistants, which differs drastically from classical community tourism with its bed and breakfasts, catering, etc. The present actual "mass" of the tourist contingent (middle-aged Estonians (45\%) with higher education (41\%), and also often backpackers with children) [11] does not correspond very well with the popular profile of the mass tourist (an alcohol-loving yahoo with a big car and a poor education). The contrast with the "bad" mass tourist, who personifies all of the side effects of tourism that are seen as negative, creates a binary opposition and thus confirms the "good" image of the cultural and elite tourist.

Upon closer examination, the concepts and interpretations of tourism policy thus often prove to be constructed on an implicit ideological or other basis and are empirically unjustified, and hence do not make much of a contribution towards the understanding of tourism as a local environmental and development problem or towards the elaboration of an informed tourism policy. Despite the analytical shortcomings, these are nevertheless concepts that actually function in the political arena of Kihnu, and give an impression of the political and economic tensions and debates that surround tourism on Kihnu.

The cognitive value of the development discourse reconstructed above is also limited by the fact that its fundamental concepts and oppositions are based largely on written sources, and it is questionable how representative they are as reflections of the island community's attitudes and wishes for the future. On the basis of the interviews, at least, it appears that not all inhabitants of the island characterise tourists and tourism problems in the same way. The corresponding 
"official" terms are indeed used, but with hesitation and often a little "incorrectly". The island's residents generally have an extremely poor knowledge of state and local government regulations, view them with distrust or even consider them to be utterly irrelevant to their lives. These observations allow one to evaluate that this discourse on "the protection of the cultural heritage of Kihnu", "cultural tourism" and also "mass tourism", etc., having been imported and articulated by the intellectual elite, may not adequately and sufficiently cover local agendas. This, however, calls into question the sustainability of tourism on Kihnu, one of the preconditions of which is that as many members of the community as possible have equal access to information connected with environmental and tourism organisation (Richards and Hall [33], particularly Goodall and Stabler [46]).

\section{Assessment of the influence of tourism on the cultural environment of Kihnu}

Academic, artistic and media interest and the accompanying (and often indistinguishable) tourism over a long period have not been without their influence on the attitudes and behaviour of Kihnu residents. The making of handicraft goods for sale, the singing of folk songs as a folklore ensemble, etc. is not quite the same as making everyday utensils and singing when one feels the need and for one's one pleasure. “... There exists the danger of transforming the Kihnu culture into an exoticised display window culture", it is stated in the UNESCO application [12]. Many craftspeople indeed feel exploited by academic researchers.

$\mathrm{Z}$ (an older woman) says that no one from the mainland has helped us, everyone just comes here to earn from the centuries of work and toil of our women - i.e. scientifically researching, doing business, etc., and we must see for ourselves how we manage.

Excerpt from fieldwork diary 20.10.2004

At the same time, external attention has for many clearly been beneficial, even if that is not admitted, including financially. Participation in folklore festivals and exhibitions has become an important part of many people's lives. There are undoubtedly also cases of mutually enriching and truly pleasant interaction with tourists, and many bed and breakfast owners have even developed friendships with tourists, especially return visitors.

In the summer I had students here, and they asked whether they could shout. I said of course, go ahead. They stood on the roof of their car and shouted out of pure joy. I was also glad they were able to let out their pent-up energy. (Older woman, owner of bed and breakfast.)

Excerpt from fieldwork diary 23.10.2004

Although there are few people on Kihnu who have a completely negative attitude towards tourism (according to a survey, 3\% of inhabitants are of the opinion that tourists seriously interfere with everyday work; Hurt et al: [11]; in our fieldwork we met only a couple fervent opponents of tourism), one cannot deduce from this that there is no influence. The islanders see benefits in tourism, 
for which they are willing to accept the accompanying unpleasantness. The initial reaction of almost all of the islanders is to claim that tourists do not disturb them at all, and it is only after a longer and more private discussion that one hears comments that range from mild accusations to repressed bitterness. Surveys performed during fieldwork showed that the attitude towards tourists is ambiguous even among those who earn money from tourism.

$\mathrm{He}$ (a middle-aged man, tourism entrepreneur) repeated that the number of tourists should definitely not be limited, or else he and many others would have to sell their houses and move the mainland. (...) At the same time, he sighed that he would not be working in tourism if there were something else to do. Z (an older woman) also alluded that she also felt something similar - winter knitting work is also done for sale to tourists in the summer, and the same is the case with vegetables and [home-made] bread and meat and fish...

Conversation in a store. Excerpt from fieldwork diary 20.10.2004

The conversations showed that the beaches of Kihnu are one area of conflict. Here the tourists to some extent disrupt the local inhabitants' daily rhythms, sense of security and livelihood, disturb datings between residents, playing with and using the residents' fishing boats and nets. The corresponding exhortations in the tourism brochures have an insufficient or even opposite effect - picking of the Sea Holly (Eryngium maritimum), an otherwise little-known but protected dune plant has apparently become more common precisely due to the corresponding "advertisement" in the tourism brochures.

Since Kihnu is an IBA (Important Bird Area) and an IPA (Important Plant Area) area, the influence of tourism on the natural environment should be examined from the point of view of the protection of birds and plants characteristic of this habitat type [47]. In this sense coastal areas are of critical importance, as they are home to some extremely sensitive habitat types, for instance Boreal Baltic sandy beaches with perennial vegetation, fixed coastal dunes with herbaceous vegetation ("grey dunes") (2130), shifting dunes along the shoreline with Ammophila arenaria ("white dunes") (2120) and wooded dunes, which at the same time are most attractive to tourists. As a result of extensive trampling, many protected plant species may disappear, and water erosion and the danger of drifting sand increase, so that the influence may be cumulative. Many habitat types are also threatened by camping, campfires and motor vehicle use (2130 grey dunes). The latter danger is indeed presently greater from the tractors and motorcycles of the local inhabitants.

It appears that the reduction in the agricultural use of land that has taken place in Estonia in the last decade has paradoxically raised Kihnu's tourism resistance -the greater volume of undergrowth conceals those moving in the landscape and vehicles, yards are better concealed from strangers, and also garbage is less visible on unmown and ungrazed land, and tourists do not have to compete with locals for wood for their campfires. At the same time, the overgrowing of the last Boreal Baltic coastal meadows, Fennoscandian wooded meadows, Fennoscandian wooded pastures would mean the end of a significant tourist resource (traditional open coastal landscapes) and the need to reproduce 
the tourism resource from other sources with the accompanying intellectual and financial expenditures (advertising, interpretation, training of services sector personnel).

It has been estimated that Kihnu has reached the maturity stage in the tourist area cycle Meeras [48]. Anneli Akkermann, leading tourism entrepreneur on Kihnu, confirms that the increase in the number of tourists paused in 1999, and no further growth is expected, although she does not predict a reduction in the number of tourists either [28]. These signals raise questions about the sustainability of Kihnu's tourism resource, exhaustion and reproduction, as well as the limits of use. The most important achievement for the reproduction of the tourism resource has until now been the acquisition of UNESCO recognition, which is at the same time also a part of the tourism problem.

Based on the above, it can be estimated that although the level of tolerance of Kihnu's cultural environment has not yet been surpassed, and the tourism resource has not yet been exhausted, it would be worthwhile diversifying and regulating the methods of exploitation of the resource, in order to ensure its sustainability. The present quantity of tourists is probably not the most expedient, because although mass tourism (in the neutral sense implying an abundance of tourists) has an indirect supporting influence on infrastructure and several other branches of the economy, other socially and economically desirable objectives have begun to suffer, and against this background the further development of tourism should be considered. For instance, all islanders who are capable and willing to serve tourists are already all employed in such work [27]. Any expansion would thus lead to an influx of labour, which would clearly significantly destabilise relations within this historically relatively closed community.

\section{Initial tourism carrying capacity indicators}

Indicators are used for the handy simplification of the real world in the research and planning process Mikkelsen [31]. Indicators arise from values (we measure what is important to us), but at the same time they create values (we value what we measure). Regardless of the subjectivity and ambiguity of the indicators, the use of indicators as a means of cognition is apparently inevitable.

In this work we offer explorative micro-level indicators that have the objective of raising initial questions and working hypotheses. These may not be easily measurable or even provable, but they are easy to use and their grounds are more transparent than several ostensibly more trustworthy and quantitative indicators that nonetheless are founded on disputable assumptions $c f$. Mikkelsen [31]. On the basis of the Pärnu County plan data, for instance, according to which $46 \%$ of the population of Kihnu is involved in hobby activities (in Pärnu County an average of $18 \%$ ) [6,7], the condition of Kihnu's cultural environment could be considered quite exemplary. Such an indicator is indeed easy to use and compare, but is uncritical - in the case of the relatively unmodernised culture of Kihnu, involvement in professionally led cultural activity may just as well be interpreted as an indicator of the degree of cultural colonisation and levelling. 
Explorative indicators that one could use concerning the lifestyle and economy of Kihnu include whether potatoes are sold in the stores on Kihnu. Potatoes are presently grown by almost all indigenous families on the island, and thus they are not for sale in stores apart from during the tourist season. It transpired from the interviews that growing potatoes on plots that are too tiny and inefficient to use a tractor (these plots are evidently relics from the horse era), are an important identity-bearing feature on Kihnu. Potato growing is one of the main topics of discussion in summer when people meet near the store, and giving up potato growing would almost lead to ostracism from the community, although in confidential discussions, residents have conceded its economic inexpedience.

If potatoes began to be sold in the stores year-round, this would point to a significant change in the way of life and mutual relations within the community. This could mean a reduction in the proportion of traditional means of subsistence or changes in specialisation within the community - for instance, a few farmers have now begun to grow more potatoes than their household requires, and they market it within the community, thereby freeing (or pushing) other families to specialise in other areas. In comparison, milk packaged in plastic bottles is already sold in the stores year-round, since the tradition of keeping one cow has almost come to an end.

Whether, for instance, firewood obtained from the local forest/wooded meadow/brush has become an object for bartering could also be considered to be an indicator of changes in communal relations or innovation - at present those families that do not have their own forest prefer to import their fuel from the mainland or use electric heating (electricity is also the main source of warmth in local government institutions), because firewood is not a traditional object for bartering within the community. The latter can also be considered to be an indicator of the success of regional policy from the point of view of sustainable development, pointing to whether government policies motivate people to use more renewable resources and sustainable innovation in the organisation of the community or, on the contrary, lead them to continue with existing nonsustainable environmental practices. Both of the above-mentioned indicators can be interpreted in more than one way - backwards practices from the point of view of national and global environmental policy objectives can be seen as valuable cultural heritage from the local and UNESCO points of view.

The influence of tourism on the cultural environment of Kihnu can also be assessed using quantitative indicators. Pursuant to a study performed in 2002, $44 \%$ of Kihnu residents estimated that tourists have no influence on their work, whereas $28 \%$ found that their work sometimes depended on tourism, while $25 \%$ depended on tourism to a great extent [11]. Apparently that $25 \%$ is a group that is lost to other (presumably traditional) branches of activity. The latter percentage definitely includes many for whom tourism is not their primary activity, i.e. craftspeople producing for sale, etc. Tourism's desirable proportion of the economy is partly a question of political agreement, but there is also some kind of more objective boundary here that is set by the fact that the community's distinctiveness as the basis of the brand constitutes the tourism resource $c f$. 
Richards and Hall [33]. If, however, one were to define this boundary and begins to carry out repeat research using a comparable methodology to that which already exists Hurt et al [11], one could obtain a convenient and measurable indicator of tourism carrying capacity.

\section{Conclusions}

The article deals with questions connected with the assessment of the tourism carrying capacity, using the example of the cultural environment of Kihnu. In the research, we used semi-structured interviews alongside direct observation and the analysis of existing research and planning documents. Moreover, we attempted to avoid the naïve presumption that the accounts provided in the sources would give a pure and reliable view of things "as they are", and we instead took a careful attitude to them as a discursive manner of producing reality.

The fundamental concepts and oppositions of the current development discourse, such as, for instance, "cultural tourism" versus "mass tourism", proved to be constructed on concealed ideological or other deliberate grounds, and empirically unjustifiable. The cognitive value of the above-mentioned development discourse is also limited by the fact that it has been reconstructed mostly on the basis of written sources. Interviews with local activists, officials and local inhabitants gave reason to estimate that this may not adequately and sufficiently cover local agendas, although it gives an impression of the tourismrelated political and economic tensions.

The present level of knowledge and the position of the social debate on tourism do not make it possible to assess the influence of tourism on the cultural environment of Kihnu with satisfactory validity. Thus we restricted ourselves to initial evaluations, and have offered some explorative indicators, with the aim of raising initial questions and formulating working hypotheses, while also referring to problems connected with the interpretation of the indicators. In the case of Kihnu, one explorative indicator could, for instance, be whether or not potatoes are sold in stores year-round, since that would make it possible to conveniently identify a whole complex of culturally significant changes.

\section{References}

[1] Parts, P.-K., Sepp, K. \& Palo, A., Kihnu kultuurikeskkonna turismitaluvusuuring [Investigation of the carrying capacity of the cultural environment of Kihnu Island], 2004 [Manuscript at Kihnu Parish Government].

[2] Kerge, A., Vihalem, M. \& Kase, U., Pärnumaa Kihnu valla üldplaneering (Arengukava). Valla üldiseloomustus (Lähteülesanne) [Pärnu County General Plan of Kihnu Parish (Development plan) Vol. 1. Overall description of parish (Terms of Reference)], Pärnu County Government: Tallinn-Tartu-Pärnu, 1994.

[3] Kerge, A., Vihalem, M. \& Kase, U., Pärnumaa Kihnu valla üldplaneering (Arengukava) Vol. 2. Eesmärkide püstitus. Strateegia. Ettepanekud [Pärnu 
County General Plan of Kihnu Parish (Development plan) Vol. 2. Establishment of Objectives. Strategy. Recommendations], Pärnu County Government: Tallinn-Tartu-Pärnu, 1994.

[4] Kerge, A., Vihalem, M. \& Kase, U., Pärnumaa Kihnu valla üldplaneering (Arengukava) 3. kd. Ettepanekud. Lühikokkuvõte [Pärnu County General Plan of Kihnu Parish (Development plan). Vol. 3. Recommendations. Summary], Pärnu County Government: Pärnu, 1995.

[5] Kihnu valla arengukava 2003-2008 [Development Plan of Kihnu Parish 2003-2008], 2002 [Manuscript at Kihnu Parish Government].

[6] Pärnu County Government, Pärnu Maakonna planeering [Pärnu County Plan], Pärnu County Government: Pärnu, 1999.

[7] Pärnu Maakonna planeering [Pärnu County Plan]. www.mv.parnumaa.ee/?page=409. 03.11.04.

[8] Pärnu County Government. Pärnu Maakonna teemaplaneering: asustust ja maakasutust suunavad keskkonnatingimused. [Pärnu County Thematic plan of environmental conditions that influence settlement and land use], Pärnu County Government: Pärnu, 2003.

[9] Paal, J., Euroopas väärtustatud elupaigad Eestis [Estonian Habitats Valued in Europe], Estonian Ministry of the Environment: Tallinn, 2004.

[10] Palo, A., NATURA 2000 metsaelupaigad [NATURA 2000 Forest Habitats], Estonian Ministry of the Environment and Eesti Loodusfoto: Tartu, 2004.

[11] Hurt, U., Raudsepp, A., Sander, K. \& Tamm, T., Kihnu valla turismiuuringu projekt [Investigation of tourism in the Kihnu Parish], Diploma thesis, Pärnu College of the University of Tartu, Department of Tourism and Hotel Management: Pärnu, 2003 [Manuscript in Library of Pärnu College].

[12] Kuutma, K., National Candidature File for Estonia: The Kihnu Cultural Space, UNESCO Proclamation of Masterpieces of the Oral and Intangible Heritage of Humanity 2003. www.unesco.ee

[13] Püsiasustusega väikesaarte seadus [Permanently Inhabited Small Islands Act]. www.riigiteataja.ee/ert/act.jsp?id=262923. 01.12.2004.

[14] Looduskaitseseadus [Nature Protection Act]. www.riigiteataja.ee/ert/ act.jsp?id=780285. 5.11.2004.

[15] McNeely, J.A., Thorsell, J.,W., \& Ceballos-Lascurain, H., Guidelines: Development of National Parks and Protected Areas for Tourism, WTO/UNEP Joint Publication: Madrid, 1992.

[16] VASAB 1996, Common Recommendations for Spatial Planning of the Coastal Zone in the Baltic Area, Adopted 22 October 1996. www.vasab.org.pl/documents.php?go=display\&ID=76. 10.12.2004.

[17] Convention for the Safeguarding of the Intangible Cultural Heritage. Adopted in Paris, 17 October 2003. http://unesdoc.unesco.org/ images/0013/001325/132540e.pdf 07.04.2004.

[18] Säästva arengu seadus [Sustainable Development Act]. www.riigiteataja.ee/ert/act.jsp?id $=874359$ 
[19] Shipp, D. \& Kreisel, B., Loving them to death? Sustainable tourism in Europe's Nature and National Parks, EUROPARC Federation: Eupen, 2001.

[20] Leesment, L., Kihnu ajalugu = Geschichte der Insel Kühno (Kihnu) [History of Kihnu Island], Tartu Ülikooli toimetused = Acta Universitatis Tartuensis / Dorpatensis. B; L, 4, University of Tartu: Tartu / Dorpat, 1942.

[21] Kalits, V., Kihnlaste elatusalad XIX sajandi keskpaigast tänapäevani: dissertatsioon ajalookandidaadi teadusliku kraadi saavutamiseks [Areas of Subsistence of Residents of Kihnu Island from the mid-19th Century to the Present Day: Dissertation for Academic Degree of PhD in History], Tartu, 1963.

[22] Levald, H., Kihnu sotsiaal-majandusliku arengu probleemidest [Problems of the Socio-Economic Development of Kihnu], Summary of Results of Short-Term Research, Tallinn-Pärnu, 1980 [Manuscript in possession of J. Leas].

[23] Levald, H., Kihnu sotsiaal-majandusliku arengu probleemid II. Lühikokkuvõte kordusuuringust, [Problems of the Socio-Economic Development of Kihnu II. Summary of Recurring Research], TallinnPärnu, 1986. [Manuscript in possession of J. Leas].

[24] Vetemaa, M., Eschbaum, R. \& Saat, T., The transition from the Soviet system to a market economy as a cause of instability in the Estonian coastal fisheries sector. Marine Policy, 30(6), pp. 635-640, 2006.

[25] Servinski, M., Linnad ja vallad arvudes [Cities and parishes in figures], Statistical Office: Tallinn, 2003.

[26] Alop, A., Eidast, A., Karing, P., Lember, J., Lend, E., Levald, H., Lips, U., Nõmmik, A. \& Uustalu A.-M., Kihnu, Manilaiu ja mandri vaheline transpordiühendus. Arengukava [The Transport Connection between Kihnu Manilaid and the Mainland], Estonian Maritime Academy: Tallinn, 2002.

[27] Akkerman, A., Turismi osatähtsusest Kihnu saarel [The Importance of Tourism on Kihnu Island]. Proc of Conference on Tourism Policy, ed. Kuura, A., Pärnu College of the University of Tartu: Tartu, pp. 52-57, 1999.

[28] Akkerman, A. Personal communication by telephone, 23 November 2004, manager of tourism and the ferry line, Pärnu-Kihnu, Estonia.

[29] Leas, J. Personal communication by telephone, 10 December 2004, Mayor of the Community of Kihnu, Pärnu-Kihnu, Estonia.

[30] Excerpt from guestbook of Kihnu Parish homepage, entered 27 May 2004, 20:27, Name: Leidur Leo. www.kihnu.ee/kylalisteraamat

[31] Mikkelsen, B., Methods for Development Work and Research. A Guide for Practitioners, Tejeshwar Singh for Sage Publications: New Delhi, 1995.

[32] Cohen, A.P., The symbolic construction of community, Ellis Horwood Ltd and Tavistock Publications Ltd: London, 1993. 
[33] Richards, G. \& Hall, D., The community: a sustainable concept in tourism development? Tourism and sustainable Community development, eds. G. Richards \& D. Hall, Routledge: London and New York, 2002.

[34] Laclau, E. \& Mouffe, C., Hegemony and socialist strategy: towards a radical democratic politics, Verso: London, 1999.

[35] Burningham, K., Environmental Values as Discoursive Resources. Values and the Environment. A Social Science Perspective, eds. Y. Guerrier, N. Alexander, J. Chase \& M. O’Brien, John Wiley and Sons: Chichester, New York, Brisbane, Toronto and Singapore, 1995.

[36] Livingstone, D.N., The Geographical Tradition. Episodes in the History of a Contested Enterprise, Blackwell: Oxford, 1992.

[37] Jones, M., The concept of cultural landscape: discourse and narratives. Landscape Interfaces: Cultural Heritage in Changing Landscapes, eds. $\mathrm{H}$. Palang \& G. Fry, Kluwer Academic Publishers: Dordrecht, Boston and London, pp. 21-52, 2003.

[38] Foucault, M., The Archaeology of Knowledge, Tavistock Publications: London, 1989.

[39] Shotter, J., Deconstructing Social Psychology, Routledge: London, 1990.

[40] Jokinen, A. \& Juhila, K., Diskursseja rakentamassa. Näkökulma sosiaalisten käytäntöjen tutkimiseen, Tampereen yliopisto: Tampere, 1991.

[41] McNeely, J. A., Thorsell, J. W. \& Ceballos-Lascurain, H., Guidelines: Development of National Parks and Protected Areas for Tourism, WTO/UNEP Joint Publication. Madrid, 1992.

[42] Boullón, R., Planificación del Espacio Turístico. Editorial Trillas: Mexico, 1985.

[43] Richards, G \& Hall, D., (eds). Tourism and Sustainable Community Development, Routledge: London and New York, 2002.

[44] Akkerman, A., Kihnu turism kihnlaste teenistuses [Tourism at Kihnu in the service of local habitants], Leaflet of Kihnurand Ltd, 1996 [Manuscript in possession of J. Leas].

[45] Kihnu valla arengukava lähtematerjalid [Terms of Reference for Development Plan of Kihnu Parish], 1999 [Manuscript at Kihnu Parish Government].

[46] Goodall, B. \& Stabler, M., Environmental standards and performance measurement in tourist destination development. Tourism and Sustainable Community development, eds. G. Richards \& D. Hall, Routledge: London and New York, 2002.

[47] Lutsar, L. \& Leibak, E., (eds). Eesti ranna- ja luhaniidud [Estonian Coastal and Flood Plain Meadows], Estonian Fund for Nature and Danish WWF: Tallinn, 1996.

[48] Meeras, L., Pärnumaa puhkemajanduse ja turismi potentsiaal [The Potential for Vacationing and Tourism in Pärnu County]. Diploma thesis. Pärnu: Pärnu College of the University of Tartu, Department of Tourism and Hotel Management, 2002 [Manuscript in Library of Pärnu College]. 